Vol 41 (2016) No 184 131-146

\title{
Challenges of the Professionalization of Department Heads in Higher Education: A Qualitative Study in Turkey *
}

Kadriye Dimici ${ }^{1}$, Fatma Nevra Seggie ${ }^{2}$, Özge Hacifazlioğlu ${ }^{3}$, Ayşe Caner ${ }^{4}$

\begin{abstract}
Professionalization of department heads is a relatively recent concept of interest in the higher education administration domain and as such few studies in the extant literature address the training needs of department heads and how they become more professionalized in their work. The aim of this study is to address this gap in the literature by examining the perceptions of department heads working in public and private universities in Turkey regarding the level of professionalization in their roles as leaders of departments.

The authors of this study use a qualitative approach to interview fourteen participants from four universities in Istanbul. Thematic analysis is used to determine the main and sub-themes based on the statements of the participants. The findings of this study suggest that being a department head is not a professionalized field in Turkey and the department heads generally express negative opinions about the roles because of a variety of problems that occur as a consequence of some problems related to the position. In the light of the findings, there may be a need to start a discussion as to how department heads are chosen and trained in both public and private universities in Turkey.
\end{abstract}

Keywords

Higher education

Professionalization

Department heads

Academic leadership

Thematic analysis

Article Info

Received: 29.11.2015

Accepted: 03.04.2016

Online Published: 27.04.2016

DOI: 10.15390/EB.2016.6149

\section{Introduction}

The role of academic leadership is of undoubted importance and this is reflected by in the academic literature. However, scholarship in academic leadership generally focuses on presidents and deans (Cohen \& Marsh, 1974; Kerr 1984; Sergiovanni \& Corbally 1984; Kerr \& Mc-Dade, 1986; Tucker \& Bryan, 1991; Amey \& Twombly, 1992; Turner, 2002; Twombly, 1998; Wolverton \& Gmelch, 2002). What is common to all these studies is the understanding that "leadership is no longer a one-man phenomenon; rather, it is a collective activity" (Hacifazlioglu, 2010a, 2010b). Included in this leadership collective is the role of department head, which is partly leadership and part administrative in its makeup. Yet, we see a relative paucity of studies actually addressing the

\footnotetext{
* This study is derived from the Master thesis of Kadriye Dimici entitled 'Leadership of Department Heads in Higher Education and Their Professionalization as Leaders'.

1 İzmir Katip Çelebi University, School of Foreign Languages, Turkey, kadriyedimici@gmail.com

${ }^{2}$ Boğaziçi University, Faculty of Education, Turkey, nevra.seggie@boun.edu.tr

${ }^{3}$ İstanbul Kültür University, Faculty of Education, Turkey, o.hacifazlioglu@iku.edu.tr

${ }^{4}$ Boğaziçi University, Faculty of Education, Department of Educational Sciences, Turkey, caner@boun.edu.tr
} 
experiences of department heads and how they are chosen, trained or 'professionalized'. This study examines the roles, training and professionalism of department heads in Turkey.

Wolverton and Gmelch (2002) define academic leadership as the "the act of building a community of scholars to set direction and achieve common purposes through the empowerment of faculty and staff" (p. 33). Higher education scholarship reveals many examples of the success and failure of academic leaders (Finkel, Olswag, \& She, 1994; Wolverton, Gmelch, \& Wolverton, 1999; Wolverton, Gmelch, Wolverton, \& Sarros, 1999; Chliwniak, 1997; Kerr \& McDade, 1986; McDade 1987; Alison \& De la Rey, 2003; Brown, Ummersen, \& Sturnick, 2001; Schwartz, 1997; Turner, 2007; Twombly, 1998) where challenges can be gender-driven, culturally-driven or politically-driven. A careful examination of this literature demonstrates that the definition a being a department head is evolving from a traditional administrative role to more of a visionary / leadership role interacting with the university and society at large (Argyris \& Cyert, 1980; Amey \& Twombly, 1992; Gmelch \& Miskin, 1993; Tucker \& Bryan, 1991; Walton, 1997; McDade, 1987; Olson and Clark, 2009; Tierney, 2015). Gmelch and Miskin (1993) argued that deanship was more challenging than being a department head and this was the commonly accepted view until the mid-1990s. However, as the idea of leader and leadership has evolved so has the role of department head as being part of the leadership team.

At the same time as we observe the evolution of the role of department head on an international level, we also observe the the greater internationalization of the university education system in Turkey especially since Turkey became a participant in the European Higher Education Area, thus ensuring that, as with the higher education systems in the developed world, the role of the department head has become more crucial. Furthermore, the trend toward more interdisciplinary programs (UCLA, 2006; Ulusoy, 2007; ASHE, 2009 as cited in Simsek \& Hacifazlioglu, 2012) and toward universities becoming a part of the community has increased pressure on universities to have more contemporary and professional leadership teams and this of course includes the pivotal role of the department head. In such a demanding context, the department head has an important role at the core of all of these activities. Yet, experience tells us that department heads receive little or no orientation before assuming their roles as the leader of the departments. However, the strains and stresses of the role of department head are such that these department heads require professional support for their positions. In fact, some universities, in response to the need to have more professional administrators, have recruited from outside academia (Brown \& Moshavi, 2002; Land, 2003; Zusman, 2005).

This article presents the findings of a qualitative study conducted with 14 department heads in higher education in Turkey. First, we review the literature on academic leadership from the perspectives of academic administration, balance and professionalism. Then we analyze and interpret the interview data through the prism of professionalism. Finally, we provide provisional insights for policy makers, administrators and academic leaders at various levels in universities and contribute to the literature on professionalization in higher education.

\section{Purpose of the Study}

This study seeks answers for the following research questions: (1) "What are the perceptions of department heads on the development of professionalization in their roles as the leader of their departments?" and (2) Are there any differences in the professionalization of department heads in their roles in terms of university type (public/private)?

The context of the study is Turkish universities, an area that has seen limited studies regarding the roles of department heads (e.g., Akbulut \& Seggie, 2013; Hoca, 2007; Tamer, 2011; Hacifazlioglu, 2010a, 2010b).

\section{The Notion of Department Head}

In Turkey, the current higher education system has been mainly shaped by two factors since 1980s. The first one is the foundation of YÖK (Higher Education Council) in 1981 and the implementation of Law 2547 which determines the rules to be practiced in higher education 
institutions. The second factor is the influence of globalization and internationalization on Turkish higher education system starting from the 1980s. Today, there are 105 public and 73 foundation universities in Turkey (YÖK, 2014).

According to law no: 2547, the responsibility of the department heads in the Turkish Higher Education System is defined as follows: "The Head of the Department is responsible for education and research at every level in the Department and for the orderly and productive functioning of all activities within the Department." (YÖK, 1981). Department heads are chosen from among the faculty members in a department and are not required to be of a specific rank. That said, priority is by rank. So, if there is a professor in the department willing to be department head then he/she is appointed to be department head. If more than one professor wishes to be department head then an election is held and if none of the professors in the department is willing to be department then priority moves on to the associate professors with the same system and so on.

Tradition holds that academic administrators rise from within faculty ranks and pursue a career path from professor to department chair to dean, provost and, eventually president (or rector). While business and industry have placed special emphasis on career planning of their administrators, the pattern in higher education is mostly based on natural selection with little planning or preparation by the individual or the institution (Moore, 1983; McDade, 1987). Blackmore and Blackwell (2006) emphasized the challenges encountered by department chairs who survive to "mediate between the realities of higher education and the beliefs and values of the faculty" (p. 376). Therefore, the position itself comes along with the challenges. Department chairs are assumed to accept this role to make a change in the lives of their faculty while moving their departments ahead in line with some sort of vision. This is a very demanding and high stakes role. Gmelch and Miskin (1993), note that intrinsic motivation for taking on the role of department head includes an opportunity to improve the department, the need for a personal challenge, and the chance to be in control of the immediate academic environment. Furthermore, Gmelch and Miskin stated that department heads bear administrative workloads at the expense of their primary responsibilities of teaching and research.

Department heads are usually open to functioning as leaders in the department, however, most are found to have no motivation for a more demanding leadership role. Taking administrative duties brings difficulties which eventually disturbs different forms of balance in many ways. Balance in academic leadership has been an important issue that has gained interest of scholars from disciplines of psychology, higher education and sociology (Acker \& Armenti, 2004; Ashforth, 2000; Brown et al., 2001; Alison \& De la Ray, 2003; Bryman, 2007; Turner, 2007; Mangels, 2009). Most of the scholarship is based on data collected from women leaders. However what has been obvious in all these studies is that the struggle to find balance is not only unique to women but also men. Turner (2002) conducted longitudinal studies on women leaders in the United States, and revealed the dilemmas experienced by faculty women of color. These authors demonstrated that women leaders felt divided between home and academic responsibilities. Their experiences exemplify the ways women have to sacrifice family and community commitments for a certain period in their lives in order to pursue academic careers and leadership positions in particular. Another issue of balance could be based on scholarly activities and administrative responsibilities. Blackmore and Blackwell (2006); Hacifazlioglu (2010b) revealed academic leaders' struggles to keep a balance between research, teaching and leadership. Walton (1997) uses the metaphor of swimming "against the tide" to illustrate the challenges experienced in academic leadership positions. In some studies, the risks of hiring nonacademic staff are investigated (Brown \& Moshavi, 2002; Gomes \& Knowles, 1999; Zusman, 2005). These studies suggest recruiting academic staff with leadership characteristics instead of nonacademic managers in order to prevent a possible negative result inside the institution. Although our primary goal in this study is not to examine department heads' experiences of balance, it emerged as one of the sub themes within the article. We now provide an overview of the extant literature in professionalization as a leader. 


\section{Professionalization as a Leader}

The concept of professionalization can have different meanings in diverse situations. Dewey (1922) defined professionalism in education as nd the professionalizationevitable, though not wholly desirable or admirable, emerging as a result of social and economic change, the increase of people taking higher education and the demand for more education in a more developed society" (p. 419).

Almost a hundred years later the concept of "oncept of rs lateis still a high stakes issue. Although the definition of professionalism differs in different cultures and contexts, there are common themes that cut across the different cultures and contexts. Within the context of university administrators, McDade (1987) underlines the importance of "professionalism" and asserts that higher education administrators should have a "well-developed repertoire of management skills and leadership techniques to remain long as the leaders of those institutions and to ensure endurance of their institution". The dynamic nature of professionalism should also be taken into consideration since the meaning attributed and the skills required may change over time under different social and cultural conditions. In this context, the three key headline challenges noted by Kane (2010) are e importance of "professionalism" and asserts that higher education administrators should have a "well-developed repertoire oessionals and to (re)envision and articulate a new contextually informed and shared sense of professionalism. Department heads are also assumed to encounter these challenges as professionals. Among these headline challenges, interrelations in the dimensions of professionalism gets more complex due to the nature of the profession.

Hacifazlioglu (2010a) noted that being an academic leader may bring many challenges and the leader faces those to the greatest extent during the transition stage. Yet, many do not take on administrative posts with the intention of making it the main thrust of their career. In fact, as noted by Wolverton and Gmelch (2002) some of the administrators accepted the position because they feel forced to take on such roles since no one else is willing, while others say that they see it as an opportunity to help either the department or themselves professionally (Wolverton \& Gmelch, 2002; Hacifazlioglu, 2010a). In the Turkish public university context, as explained earlier, regulations require the faculty member, who holds the highest academic title (and is willing) to shoulder the responsibility of department chair. In the case where there are more volunteer of the same academic rank, a departmental election held. Although being a department chair seems undesirable in many ways, some scholars have demonstrated a willingness to be a part of the administration. As an administrator, the department chair is expected to meet the requirements of professionalism demonstrating the skills of organising, planning, evaluating, appraising, and leading towards change. Meeting all these professional requirements is not easy. The issue of training department chairs is also under discussion since department chairs may be reluctant to accept the training. However, systems such as that used in the United States could be adopted whereby training is through orientation and networking rather than the more traditional training methods.

Some studies have been conducted in order to understand the training needs of department heads and the scope of the training programs for this position. Budget and financing, legal issues, professional development, promotion and tenure issues, relationship with faculty members, ways to deal with conflicts are emphasized as the most important training needs (Aziz et al., 2005; Fogg, 2001). There are some available training programs aiming at increasing the conceptual understanding of leadership and providing opportunities for the application of leadership in practice (Huber, 1995; Fogg, 2001; Scott, Coates, \& Anderson, 2008). Some of these programs provide a supportive network for department heads and some programs are designed to be in the form of one-day or three-day orientation programs. However, there is usually negative feedback about these available programs on the grounds that they are boring and the duration is very short to cover all issues. Some also oppose the training programs because of the risk of isolating department heads from academic life. Therefore, campus leadership programs are advised in order to provide everyone with proper training in relation to their own institution (Gmelch \& Miskin, 1993). Likewise, the importance of 'communities of 
practice' for sharing the experience of colleagues in the same positions is underlined in the studies of Hacifazlioglu (2010a, 2010b) and Çetin (2013).

Considering the fact that professionalization is a new concept for department heads, it could be defined as the following: "the process of using education and certification to enhance the quality of performance of those within an occupational field" (Shanahan, Meehan, \& Mogge, 1994, p. 3). Millerson (1964), Merriam (2001) and Allen (1961) came up with some lists to explain the difference of professions from occupations. These lists include education and training, the competence of professionals ensured by examinations, a code of conduct to ensure professional integrity, performance of a service that is for the public good, and a professional association that organizes members, to be full time occupation, to be respected by society, development in literature and graduate studies. In this context, "Communities of Practice" is defined as a voluntary transformational learning process where the participants are provided opportunities to reflect upon, reify and transform their identities as leader-scholars in the profession (Wenger, 1998). In department heads' professional development paths, this type of transformational learning pursues with purposeful interaction, collaboration, and participation with others in a community of practice (Wenger, 1998).

\section{Method}

This study implements an exploratory qualitative approach using semi-structured interviews with department heads working in higher education institutions in Turkey. Since the purpose of the study was to understand the perspectives of the department heads, conducting interviews was considered to be the most appropriate data collection as it allowed us to obtain more in-depth and detailed information (Creswell, 2014). Four universities in İstanbul, the biggest city in Turkey in terms of the number of universities with 9 public and 39 foundation universities (YÖK, 2014), were included in this study. We used purposeful sampling to choose the universities, based on the criteria of access opportunities and foundation year. Two private and two public universities which were founded in different time periods were chosen in order to have a better understanding of differences in terms of department head expectancies in job responsibilities. The universities were chosen based on their foundation year so as to include different universities with a more settled management system or new organizational system. As Smith (2002) states, there are some important differences between old and new universities or public and private universities in terms of management and leadership.

The main criterion to choose the participants was to have at least two years of experience as a department head since it was important for a department head to have a good grasp of his/her responsibilities and context and we felt that two years was sufficient time to do this. Fourteen participants were interviewed for this study. Another criterion for participant selection was that participants worked in the same faculties in different universities so that similarities and differences between universities could be better explored. Seven participants from two public universities and seven participants from two private universities were interviewed face to face. There are more details about the participants in Table 1 below. As can be seen there, six female and eight male department heads were included and the academic rank of twelve of the participants was Professor. The ages of the participants range from in their forties to seventies and their length of time as a department head ranges from two years to nine years. Finding participants was a challenge because many potential participants were too busy or impossible to contact. Due to these challenges, the data collection period lasted for seven months between June 2013 and December 2013. Participants were assured of the confidentiality of the study, and they were provided with a consent form which explains the aim and scope of this study. Both the names of the participants, and the the university names were coded. For the names of universities $\mathrm{A}, \mathrm{B}, \mathrm{C}$ and $\mathrm{D}$ were used and each participant from these universities was coded as A1, A2 etc. 
Table 1. Demographic Information about the Participants

\begin{tabular}{|c|c|c|c|c|c|c|}
\hline $\begin{array}{l}\text { Participant } \\
\text { Code } \\
\end{array}$ & Gender & Title & $\begin{array}{l}\text { University } \\
\text { Type }\end{array}$ & Age & $\begin{array}{l}\text { Department } \\
\text { Head Experience }\end{array}$ & $\begin{array}{l}\text { Department } \\
\text { Size }\end{array}$ \\
\hline A1 & Female & Prof. & Public & $50-60$ & 2 years & $\begin{array}{l}\text { Staff: } 20 \\
\text { Students: } 250\end{array}$ \\
\hline A2 & Male & Prof. & Public & $50-60$ & 4 years & $\begin{array}{l}\text { Staff: } 20 \\
\text { Students: } 500\end{array}$ \\
\hline A3 & Female & Prof. & Public & $40-50$ & 2 years & $\begin{array}{l}\text { Staff: } 20 \\
\text { Students: } 200\end{array}$ \\
\hline A4 & Male & $\begin{array}{l}\text { Assoc. } \\
\text { Prof. Dr. }\end{array}$ & Public & $40-50$ & 2 years & $\begin{array}{l}\text { Staff: } 30 \\
\text { Students: } 200\end{array}$ \\
\hline B1 & Male & Prof. & Public & $40-50$ & 4,5 years & $\begin{array}{l}\text { Staff: } 12 \\
\text { Students: } 150\end{array}$ \\
\hline B2 & Male & Prof. & Public & $60-70$ & 9 years & $\begin{array}{l}\text { Staff: } 5 \\
\text { Students: } 150\end{array}$ \\
\hline B3 & Female & Prof. & Public & $50-60$ & 2 years & $\begin{array}{l}\text { Staff: } 15 \\
\text { Students: } 150\end{array}$ \\
\hline $\mathrm{C} 1$ & Male & Prof. & Private & $60-70$ & 3 years & $\begin{array}{l}\text { Staff: 15, } \\
\text { Students: } 250\end{array}$ \\
\hline $\mathrm{C} 2$ & Female & Prof. & Private & $70-80$ & 8 years & $\begin{array}{l}\text { Staff: } 8 \\
\text { Students: } 90\end{array}$ \\
\hline $\mathrm{C} 3$ & Female & Prof. & Private & $50-60$ & 6 years & $\begin{array}{l}\text { Staff: } 8 \\
\text { Students: } 600\end{array}$ \\
\hline D1 & Male & $\begin{array}{l}\text { Asst. Prof. } \\
\text { Dr. }\end{array}$ & Private & $50-60$ & 4 years & $\begin{array}{l}\text { Staff: } 8 \\
\text { Students: } 600\end{array}$ \\
\hline D2 & Male & Prof. & Private & $60-70$ & 2 years & $\begin{array}{l}\text { Staff: } 7 \\
\text { Students: } 600\end{array}$ \\
\hline D3 & Female & Prof. & Private & $50-60$ & 5 years & $\begin{array}{l}\text { Staff: } 5 \\
\text { Students: } 200\end{array}$ \\
\hline D4 & Male & Prof. & Private & $60-70$ & 7 years & $\begin{array}{l}\text { Staff: } 10 \\
\text { Students: } 300\end{array}$ \\
\hline
\end{tabular}

The interview questions were developed based on the research questions of the study and other similar studies in the literature (e.g., Spendlove, 2007; Eddy \& VanDerLinden, 2006; Scott et al., 2008). In the interviews, open-ended questions with the help of some probing questions were used and the "indirect questioning method" was utilized to decrease the effect of social desirability bias of the participants. This was done by making the participants think and answer using the perspectives of other people through the questions. Before the interviews, the questions of this interview were approved by the Research Ethics Committee of Boğaziçi University. Maxwell (1996) notes the potential for bias and the threat to validity and refers to a researcher's tendency to filter information through his or her own prior experiences. We acknowledge that these experiences can become a source of bias, and were very careful to minimize the risk of allowing our own assumptions to influence the data collection and data analysis process.

A pilot study with two participants was conducted to review the interview questions and determine their appropriateness for this study. Some questions were edited after the pilot studies. All interviews were conducted in Turkish and later translated into English. The interviews were mostly conducted in the workplaces of the participants (based on their requests) and lasted from 25 minutes to 70 minutes. For all but one of the interviews, the participants gave consent to the interview being digitally recorded and as such thirteen out of the fourteen interviews were recorded. 
The interviewer began by asking participants demographic questions that included age, gender, academic title, size of the department, length of time in academia and length of time as a department head. Then questions were asked to explore how research participants were assigned to their position, their motivation and professional preparation, their perception of being a department head within the context of Turkish higher education, the challenges and opportunities of being a department head and their suggestions for future professional development of department heads.

After the data collection ended, the recorded interviews were transcribed and these transcriptions were sent to the participants for a 'member check' to ensure the accuracy of the transcript (Creswell, 2014). Any requested changes were incorporated into the document and the data analysis period began. After the transcription of the data, thematic analysis was used for data analysis by making use of common themes and codes emerging in the interviews (Ryan \& Bernard, 2003). The topics or codes which emerged a lot in the statements of the participants were noted down and the pseudonym of the participants was used for each occurring theme. After all of these codes were listed, they were gathered under the similar sub-themes and main themes respectively.

\section{Results}

The findings of this study were analyzed through thematic analysis and two main themes supported by sub-themes emerged based on the statements of the participants about their position as a department head.

Table 2. Main and Sub-Themes

\begin{tabular}{ll}
\hline Main Themes & Sub-Themes \\
\hline & 1-a Eligibility for this role \\
1- Perceptions on Being a Department & 1-b Reluctance \\
Head & 1-c Middle position \\
& 1-d Balance between academic and administrative works \\
& 1-e Preparation and adaptation \\
2- Perceptions on the Extent of & 2-a Indifference to professionalization \\
Professionalization & 2-b In-service training \\
& 2-c Non-academic manager \\
\hline
\end{tabular}

\section{Perceptions on Being a Department Head}

Participants frequently discussed the scope of being a department head and their assignment process as a department head. This main theme is discussed under five sub-themes, all of which emerged as a result of the categorizations of similar codes/topics the participants emphasized in the interviews. Under the first sub-theme, eligibility for this role, thirteen participants expressed the dissatisfaction with the selection of department heads based on the title:

I do not think that experience and title are important so this position needs to be on younger academicians' hands because the job includes a lot of bureaucratic work and the younger generations may have creative thinking skills. The Law needs to be flexible since I do not want to be assigned for this role just because of my title (B3).

The participants often stated that they were assigned to this role against his or her will. Some participants pointed out that this role needs to be undertaken by different faculty members in turn.

The second sub-theme, reluctance, was often discussed by the participants and they shared the reasons of reluctance. The most mentioned reason was the undesirable administrative tasks since this position has a high workload and comes with a lot of responsibility. Another reason was the lack of authority allowed to the department heads in comparison to the amount of responsibility inflicted upon them. As one of them explained: 
When I tell the staff that I do not have the authority to give permission, I am regarded as disrespectful. I cannot recruit them, give them permission to do things or dismiss them, so they have no reason to respect me (D4).

The lack of incentives was also an important reason for this reluctance. Both public and private university department heads stated that they do not get an increase in their salaries. Whereas, public university department heads were obliged to offer only five hours of courses a week (approximately a 50\% reduction in course load), which could be considered an incentive, private university department heads that participated in our study did not have this incentive. Because of their reluctance, some participants expressed their eagerness to finish their period as a department head:

If the law permits, I would be very happy to transfer the responsibility to younger colleagues. I do not adopt the titles attached to me since I was never interested in managerial tasks and I am not a person who is in pursuit of a position of authority $(\mathrm{C} 2)$.

A few participants who were chosen after an an election or were recruited as a founding department head expressed some positive opinions. Some participants also stated that this role is undertaken by some people because of the prestige it has.

Ten participants expressed the problem of being in a position at the lowest level of higher education administration and the third sub-theme, middle position, emerged. Because of this position, they pointed out that they could not make decisions on their own easily. Therefore, some regarded this role as symbolic and stated that they acted as a gatekeeper between academicians and top management. One of them shared his idea on this topic:

There is no opportunity to practice things stated in legislation in private universities. No one asks you. You just get instructions from the boss and apply them. This position is also limited in public universities, but we could practice what the law requires there whereas we are told what to do here. If you try to do something similar to what you would do in a public university, they may show you the door. In a public university, you have a University Council and if you are a good player, you can achieve things, but here no such Council exists (D4).

Six participants discussed the concerns related to the top management because they recruit the staff for the department and they show unequal behaviors in responding to the demands of the departments. Although this could be considered good for department heads who have a good relationship with top management, there might be some problems too:

Department heads that get along with the top management have faster and easier responses to the demands of their departments. But the situation may sometimes arise whereby top management asks for something which may not satisfy the staff in the department, leading to problems in persuading staff in the department (B3).

As a result of the middle position and its requirements, providing a balance is needed in the department and the fourth sub-theme, balance between academic and administrative works, was often addressed. Because of this position, the participants made sacrifices from their research and this led to concerns about their primary roles of being an academician. Some participants were more optimistic about sacrificing time for this position. They emphasized that these tasks need to be completed by someone in the department and these tasks do not lead to isolation from academic life (unlike the case for deans and rectors).

Deans become separated from academic life but you are both a manager and faculty member at the same time and you do not become distant from academic life. Besides, you have better relations with students while having this position (D2). 
Because most participants were reluctant to take this position, they all pointed out that they did not get any pre-service training for this role, therefore, the fifth sub-theme, their preparation and adaptation process as a department head was discussed. Experience as a vice-department head or research assistant was the most useful technique for adapting to this role. It was also often verbalized that this job was not a very difficult job which required training. Reading relevant materials and the legislation were suggested ways of preparation as well as observing relationships and learning things by trial and error.

\section{Perceptions on the Extent of Professionalization}

During the interviews, participants often talked about the concept of 'profession', preparation and training for their roles as well as the possibility of a department head that was not from academic life, so this main theme, perceptions on the extent of professionalization, emerged supported by three sub-themes: indifference to professionalization, in-service training and non-academic manager.

Under the first sub-theme, indifference to professionalization, it was often argued that being a department head was not really a profession. They did not regard this position as a profession because they consider themselves to be academics before everything else and they had not sought a career in this position:

I think a serious academician does not crave long years in this role and everyone in the department needs to fulfil this role for some time but being professional for this role is the influence of marketability again. Doing things randomly may mean making a mistake and losing money. We can manage academic issues but losing money is not something we understand or would like to deal with (B1).

As can be seen in the statement of this participant, being professional was often connected to the influence of marketability and financial issues. Some participants preferred being a role model rather than a professional and they suggested that being professional was more necessary for the top management. The type of university was often argued to be important because in private universities, the scope of professionalization was determined by the Board of Trustees. The risks of working as a department head in a private university were discussed since they needed to be more careful to keep their positions.

In terms of the second sub-theme, in-service training, some ideas on the scope of a training program for this role were pointed out whereas some participants regarded the training programs as unnecessary because learning the legislation, talking to other heads and experience were enough for this role.

The most frequently mentioned training was getting courses on human relations and behavioral sciences and package programs:

Training on human relations could be very beneficial or at least an academic orientation program which gives information about the academic parts of a university and their responsibilities inside the university could be offered, however, I have never witnessed such a program so far (D4).

Some argued the necessity of getting an MA degree in educational sciences, and leadership education. The importance of talking to other department heads was addressed by one participant. The department heads of other universities in his department organize meetings each year and this meeting is important for him, providing him the opportunity to share his experiences. Unfortunately his request for funding to attend this meeting was rejected by his university.

Considering the fact that almost all participants were not so happy with being a department head, the possibility of a non-academic person was argued by the participants and these ideas were categorized under the third sub-theme, non-academic manager. 
Four participants expressed positive opinions on a non-academic manager in the department while ten participants were opposed to this idea. The participants favoring this possibility pointed out that this would leave faculty more time to focus on doing research. However, the necessity of being in tune with the higher education context was required for such a person:

Management is related to personality, so someone outside academic life may be both good or bad. Department heads do not get any money for this role, but professional people will get money for this. It is difficult to talk about this without knowing the procedures for choosing such a person. Maybe a better idea would be to professionalize an academic person and confirm that he/she can work in this position until retirement (A2).

Similarly, another participant used the term 'academically professionalized person' by pointing out that people having this role as a department head needed to have academic respect and recognition so as to be called professional.

People were against the idea of a non-academic manager mostly because such a person would not be able to understand the dynamics of the department and harm the traditional university understanding, therefore some suggested the concept of 'co-head'. There could be a division between academic and administrative works of the department and a faculty member could be the head for academic works:

Yes, a professional administrator may act as a department head, but he/she needs to do that together with an academician. He may not understand the soul of academic life. Professional administration is a good idea as long as it is co-headed with an academician. It may decrease the workload of staff (C3).

The existence of administrative staff in public universities was connected to the concept of cohead since they facilitated their roles; however, private university department heads did not have the opportunity of having separate administrative staff such as a secretary. Some private universities recruit research assistants to help department heads, but there are some universities who do not want to pay for the research assistants and leave the department head to do all the tasks of the department alone.

\section{Discussion}

The purpose of this study was to learn about the perceptions of the department heads working in public and private universities in Turkey regarding the development of professionalization in their roles. This was realized through face to face interviews with fourteen department heads.

The participants of this study usually expressed that they were reluctant to take this role because of high workload and a lack of incentive. They were mostly assigned to this role and they showed the characteristics of extrinsic motivation for becoming a department head as suggested by Gmelch and Miskin (1993). We were under the impression that most participants had never thought about their roles as a department head and they were mostly reluctant to talk about this position. Through the interview questions, we noticed that they started to look at their positions from a different standpoint. We think this was mostly because of the fear of losing their job although we stated several times that confidentiality was very important for this study. Also, they tended to identify themselves with their academic identity all the time, so this might also explain the reluctance to talk.

One of the most important reasons of reluctance was found to be the obligation of having the right title by law for this position. We got the impression that most participants would volunteer to quit this position if they had a chance, so in Turkey, it is not the appropriate training or certificate that determines the department heads, but the academic rank is important (Millerson, 1964). Despite the 
emergence of professionalization in the recent literature, accountability is a more preferred concept in the current context of higher education (Zusman, 2005). The findings of this study also showed that department heads were usually charged with responsibility and accountability for this position, however they were not provided with the necessary authority or support to realize these responsibilities

Department heads were found to have no training and this is highly supported by the earlier studies (Bessa \& Goldman, 2001; Zusman, 2005). Because things are done in a non-professional manner, this position was considered non-professional in earlier studies. Likewise some participants in this study indicated that they made use of trial and error technique to adapt to this role. However, there were also participants who have the opinion that younger academics could be more innovative in these tasks and the criterion of priority for senior rank needs to be abolished (Gmelch \& Miskin, 1993). Although not having pre-service training was the tendency in the studies of other countries too, there were some attempts to offer training and orientation programs in the other countries. However, in this study participants, on the whole, showed no real eagerness for training programs. In our opinion, this could be because of the characteristics of academicians in Turkey because they usually consider themselves successful based on their academic studies instead of finding out ways to become effective in managerial tasks and teaching. Moreover, they also regard this role as a temporary position and as such may consider the training a poor investment of time. We have found in our earlier studies and trainings with the department heads that no matter how trained and how qualified academic administrators are, when appointed to a new institution or a new position, they need to get support to make a smooth transition to the new working context. In line with this idea, Argyris (1993) uses the notion of double-loop learning in a community of practice, which enables professionals to not only reflect upon their performances and take actions but also to make a substantive difference in their professions. We found limited research literature that specifically addresses the development of department heads. But we infer from the aforementioned studies and our current study that communities of practice may promote professional development when scholars and practitioners in higher education work together. The findings of this study are expected to open a platform for discussion to develop alternative methods to enhance the effectiveness of department heads.

In this study, department heads appeared to deal with many challenges, and at times they paid for career advancement through sacrifices. This is similar to the experience of women leaders, who try to maintain balance between academe and leadership (Hacifazlioglu, 2010b). As found by Hacifazlioglu, each leader's analysis of his or her situation affirms his or her view of balance as subjective. Balance takes different and nuanced forms at different times in each person's life. Relevant factors include age, energy level, family situation, attitude towards work, and gender (Mangels, 2009 as cited in Hacifazlioglu, 2010b). Further studies could be conducted to examine department heads' interpretation and practice of "balance". The findings of our study confirmed that the department heads continue to pursue a balance in private and professional life, and research, teaching and leadership. To do this they need "leader-scholar support networks" both online and face to face to help them develop throughout their careers both as a scholar and as a leader.

As explained above, the position of being a department head was not regarded as a profession by most participants because their academic identity outweighs the departmental head identity. Due to this tendency, the possibility of a non-academic manager was welcomed by some participants (Mech, 1997 as cited in Land, 2003). However, this possibility was also mentioned in association with potential negative effects it might have on the academic atmosphere of a university similar to the previous studies (e.g., Brown \& Moshavi, 2002; Gornitzka \& Larsen, 2004). We also think that in the current context of higher education in Turkey, such a decision could be risky, so academicians who are volunteering to take on this role need to be assigned for this role and they need to be rewarded based on their success.

In terms of the training programs that could be beneficial for department heads, participants shared similar ideas to the earlier studies. Workshops or package programs about legislation, 
communication and stress management were often suggested by participants (Aziz et al., 2005). However, as opposed to that study, none of our participants included budgeting as a training need because they often pointed out that top management was responsible for financial issues. In contrary to available training programs in other countries, no training program was known to exist by the participants of this study (Huber, 1995; Fogg, 2001; Scott et al., 2008). The meeting of the department heads in the same department was addressed in one participant's statements and this is similar to the suggestion of Hacifazlioglu (2010a) for creating communities of practice since people might have an opportunity to share experience with the people in the same positions. The attempts of a few universities in Turkey to open some training programs for leadership in higher education were not known by the participants, implying that these attempts have not been publicized enough. Department heads need to get training for this role since management is different from teaching and research. Planning comprehensive programs could be difficult for now in Turkey but one-day orientation programs could be started by the universities immediately.

\section{Conclusion}

The findings of this study indicate that department heads usually have some problems related to their position and these problems are mainly the lack of incentives for this role, high workload, responsibility without enough authority and the obligation by law to be assigned as department heads. More active and professional department heads are sought, however, the participants of this study are not at the that level of professionalism yet. Therefore, there needs to be some regulations on the scope of this position in Turkey. For example, the prioritization of academic rank could be abolished and volunteer faculty members could be chosen for this role and they could be offered some orientation programs before starting this role. Increase in the salaries, other types of initiatives, and giving them a chance to recruit staff for their departments are also among the suggestions we make. Furthermore, considering the difference of workload between public and private universities, the administrative staff in public universities could also be trained in order to help the department heads and some regulations could be prepared for private universities to determine the number of staff for each department and oblige the university to recruit administrative staff to help the department heads.

To make this position more attractive and recognized in Turkey, some professional associations for department heads could be organized so that the voices of department heads could be heard more on issues that affect them such as their working conditions. It is also important to have more research conducted in this area to improve our understanding further. To conclude, the concept of being a department head could be conceived as a separate role and professional identity.

\section{Suggestions}

Based on the conclusions of this study, there are some tentative recommendations for future research and practice. First of all, this study includes a limited number of universities and participants in one city so it cannot be generalized to the rest of the higher education system in Turkey. So more participants and more cities in Turkey could be covered in a nationwide study involving both quantitative and qualitative research approaches. Likewise, a study including the different levels of administrators could be conducted. A needs analysis could be prepared to determine the possible training programs for department heads and some pilot practice of these training programs could be designed and shared in a study. In this way, the literature on the professionalization of department heads will accumulate and provide the future researchers with the chance for valid and comparable data. 
Higher education institutions need to develop a mechanism to select and support department chairs. In our earlier studies we found that providing standard seminars to department heads do not have a significant effect. However, workshops and practice-oriented trainings are preferred by the heads. In various academic platforms and in our studies the notion of "Communities of Practice" has been mentioned many times. Creating such a culture is not an easy task since academic environments encourage both collaboration and competition. In house workshops needs to be supported as well as professional workshops organized by professional leadership organizations. Sustaining an ongoing professional growth for department chairs has been an issue that needs further research. In this context, "Action Research" could serve as one of the main instruments that helps department chairs to implement change in their departments as well as sustaining and ongoing development.

This study is also a call for policy-makers and authorities to reconsider and revise the policies of the appointment of department heads. There could be new regulations in the Higher Education Council Law that would encompass changes in selection criteria and procedures as well as their responsibilities, and the appointment of department heads. Ideally, the department heads should be selected by academic members of the department among the willing candidates regardless of their academic rank. Department heads would share technical and bureaucratic responsibilities among the academic members and act mainly as a leader and facilitator of teaching and research within the department. Such change would also require lowering the teaching loads as well as bureaucratic and technical assistance and support in tasks such as budgeting, planning and evaluating the administrative staff at faculty and university level. All these changes are expected to increase the willingness and intrinsic motivation of faculty to volunteer for the position and ultimately contribute to the effective accomplishment of the job.

It is also expected that department heads themselves understand the importance of their position and increase their motivation to be more effective and contribute to their department. Department heads could be the pioneers to start orientation programs for themselves and initiate the development of 'department head' networks through organizing events. 


\section{References}

Akbulut, M., \& Seggie, F. N. (2013). Leadership effectiveness in Turkish state universities. The Business E Management Review, 4(1), 129.

Amey, M. J., \& Twombly, S. B. (1992). Revisioning leadership in community colleges. The Review of Higher Education, 15(2), 125-150.

Acker, A., \& Armenti, C. (2004). Sleepless in academia. Gender and Education, 16(1), 273-324.

Alison, M., \& De la Rey, C. (2003). South African women leaders in higher education: Professional development needs in a changing context. McGill Journal of Education, 38(3), 407-420.

Ashforth, B. E. (2000) . All in a day's work. Academy of Management Review, 2, 472-493.

Argyris, C., \& Cyert, R. M. (1980). Leadership in the 80s: Essays on higher education. Retrieved from ERIC databases (ED215609).

Argyris, C. (1993). Knowledge for Action. A guide to overcoming barriers to organizational change. San Francisco: Jossey Bass.

Allen, L. A. (1961). The growth of professionalism in the adult education movement, 1928-1958: A content analysis of the periodical literatüre (Unpublished doctoral dissertation). University of Chicago, US.

ASHE. (2009). ASHE Higher Education Report (Vol. 35, No. 2). San Francisco, CA: Jossey Bass.

Aziz, S., Mullins, M. E., Balzer, W. K., Grauer, E., Burnfield, J., Lodato, M. A., \& Cohen-Powless M. A. (2005). Understanding the training needs of department chairs. Studies in Higher Education, 30(5), 571-593.

Bessa, J. L., \& Goldman, P. (2001). Leadership ambiguity in universities and K-12 schools and the limits of contemporary leadership theory. The Leadership Quarterly, 12, 419-450.

Blackmore, P., \& Blackwell R. (2006). Strategic leadership in academic development. Studies in Higher Education, 31(3), 373-387.

Brown, G., Ummersen, V. C., \& Sturnick, J. (2001). From where we sit: Womens perspectives on the presidency. Advancing womens leadership. Washington DC: American Council on Education.

Brown, F. W., \& Moshavi, D. (2002). Herding academic cats: Faculty reactions to transformational and contingent reward leadership by department chairs. Journal of Leadership \& Organizational Studies, $8,79-93$

Bryman, A. (2007). Effective leadership in higher education: A literature review. Studies in Higher Education, 32(6), 693-710.

Chliwniak, L. (1997). Higher education leadership: Analyzing the gender gap. Retrieved from ERIC databases (ED410847).

Cohen, M. D., \& Marsh, J. G. (1974). Leadership and ambiguity: The American college president. New York: McGrawHill.

Creswell, J.W. (2014). Research Design: Qualitative, Quantitative, and Mixed Methods Approaches (4th ed.). Sage Publications.

Çetin, M. (2013). Yükseköğretim yönetimi ve liderliği lisansüstü programlarının incelenmesi. Ankara: Nobel Akademik Yayıncilı.

Dewey, J. (1922). Culture and Professionalism in Education. New York: Bulletin of the American Association of University Professors, 9(8), 51-53.

Eddy, P. L., \& VanDerLinden K. E. (2006). Emerging definitions of leadership in higher education: New visions of leadership or same old "hero" leader?. Community College Review, 34(5), 5-26.

Fogg, P. (2001). Can department heads be trained to succeed?. The Chronicle of Higher Education, 48, A10-A11.

Finkel, K., Olswang, S. G., \& She, N. (1994). Child, birth and pregnancy for women faculty. The Review of Higher Education, 17(3), 259-270. 
Gmelch, W. H., \& Miskin, V. D. (1993). Understanding the challenges of department chairs. In Leadership Skills for Department Chairs (pp. 3-18). Bolton, MA: Anker.

Gomes, R., \& Knowles, P. A. (1999). Marketing department leadership: An analysis of a team transformation. Journal of Marketing Education, 23(1), 164-174.

Gornitzka, A., \& Larsen, I. (2004). Towards professionalization? Restructuring of administrative workforce in universities. Higher Education, 47(3), 455-471.

Hacifazlioglu, Ö. (2010a). Yükseköğretimde lider olarak göreve uyum sağlama süreci: Türkiye ve Amerika'dan kadın liderlerin deneyimleri. Educational Sciences: Theory \& Practice, 10(4), 2221-2273.

Hacifazlioglu, Ö. (2010b). Balance in Academic leadership: Voices of women leaders from Turkey and the U.S. Perspectives in Education, 28(2), 51-63.

Hoca, E. (2007). Bir vakıf üniversitesinde eğitim yönetimi alanındaki ideal lider tipi özelliklerinin araştırılması (Unpublished master's thesis). Yeditepe University, Institute of Social Science, İstanbul.

Huber, N. S. (1995). Leadership in higher education: Engaging the department heads. Retrieved from http://www.u.arizona.edu/ nhuber/LeadHighEd.pdf

Kane, C. (2010). Eloborating Professionalism: Studies Practice and Theory. London: Springer.

Kerr, C. (1984). Strengthening leadership in colleges and universities: A report of the commission on strengthening presidential leadership. Washington: The Association of Governing Boards of Universities and Colleges.

Kerr, C., \& McDade. S. (1986). The many lives of academic presidents. Washington: Association of Governing Boards of Universities and Colleges.

Knight, J. (1997). Internationalization of higher education: A conceptual framework. In J. Knight, \& H. De Wit (Eds.), Internationalization of higher education in Asia Pacific countries (pp. 5-19). Amsterdam: European Association for International Education.

Knight, J. (2004). Internationalization remodeled: Definition, approaches, and rationales. Journal of Studies in International Education, 8(1), 5-31.

Land, P. C. (2003). From the other side of the academy to academic leadership roles: Crossing the great divide. New Directions for Higher Education, 124, 13-20.

Mangels, S. E. (2009, April, 13-19). Does balance matter? The relationship between work-life balance and success for women college presidents. Paper presented at AERA Conference, San Diego.

Maxwell, J. (1996). Qualitative research design. Thousand Oaks, CA: Sage.

McDade, S. A. (1987). Higher education leadership: Enhancing skills through professional development programs. Texas: Association for the Study of Higher Education.

Merriam, S. B. (2001). Andragogy and self-directed learning: Pillars of adult learning theory. New Directions for Adult and Continuing Education, 89, 3-13.

Millerson, G. L. (1964). The Qualifying Association: A Study on Professionalization. London: Routledge \& Kegan Paul.

Moore, K. M. (1983). Examining the myths of administrative careers. AAHE Bulletin, 35(9), 3-7.

Olson, K., \& Clark, C. (2009). A signature pedagogy in doctoral education. Educational Researcher, 38, 216-221.

Ryan, G. W., \& Bernard, H. R. (2003). Techniques to identify themes. Field Methods, 15(1), 85-109.

Schwartz, R. A. (1997). Re-conceptualizing the leadership roles of women in higher education: A brief history on the importance of deans of women. Journal of Higher Education, 68(50), 502-522.

Scott, G., Coates, H., \& Anderson, M. (2008). Learning Leaders in Times of Change: Academic Leadership Capabilities for Australian Higher Education. Australian Learning and Teaching Council (ALTC).

Sergiovanni, T. J., \& Corbally, J. E. (1984). Leadership and organizational culture. Chicago: University of Illinois. 
Shanahan, T., Meehan, M., \& Mogge, S. (1994). The Professionalization of the Teacher in Adult Literacy Education. Philadelphia: University of Pennsylvania, NCAL.

Spendlove, M. (2007). Competencies for effective leadership in higher education. International Journal of Educational Management, 21(5), 407-417.

Smith, R. (2002). The role of the university head of department. Educational Management $\mathcal{E}$ Administration, 30(3).

Şimşek, H. \& Hacıfazlıŏlu, Ö. (2012). Interdisciplinary new university: A model for Faculties of Arts and Sciences in Turkey. Educational Sciences: Theory and Practice (Kuram ve Uygulamada Eğitim Bilimleri Dergisi). 12 (2): 731-749. (Indeks: SSCI).

Tamer, B. (2011). The relationship between transformational leadership styles and organizational culture types with respect to gender differences in public and private universities (Unpublished master's thesis). Dokuz Eylül University, Institute of Social Science, İzmir.

Tierney, W. G. (2015, October, 14-16). Barriers to Innovation and Creativity in Higher Education. Paper presented at the $1^{\text {st }}$ International Higher Education Conference, Bosphorous University, İstanbul.

Tucker, A., \& Bryan, R. A. (1991). The academic dean: Dave, dragon and the diplomat. New York: Macmillan.

Turner, C. S. W. (2002). Women of color in academe: Living with multiple marginality. Journal of Higher Education, 73(1), 74-93.

Turner, C. S. W. (2007). Pathways to presidency: Bibliographical sketches of women of color firsts. Harvard Educational Review, 77(1), 1-38.

Twombly, S. (1998). Women academic leaders in a Latin American university: Reconciling the paradoxes of professional lives. Higher Education, 35, 367-397.

UCLA. (2006). UCLA's Institutional Proposal to WASC May 12.

Ulusoy, G. (2007). Disiplinlerarası araştırma ve eğitim. In C. C. Aktan (Ed.), Değisim çă̆ında yükseköğretim: Global trendler-paradigmal yönelimler (pp. 389-398). İzmir: Yaşar University.

Walton, S. (1997). UK women at the very top: An American assessment. In H. Eggings (Ed.), Women and managers in higher education (pp. 70-88). UK: Open University.

Wolverton, M., Gmelch, W. H.; Wolverton, M. L. (1999). The impact of role conflict and ambiquity on academic deans. Journal of Higher Education, 70(1), 122132.

Wolverton, M., Gmelch W. H., Wolverton M. L., \& Sarros J. C. (1999) Stress in academic leadership: US and Australian department chairs/heads. Review of Higher Education, 22, 165-185.

Wolverton, M., \& Gmelch, W. H. (2002). College deans leading from within. Westport, CT: American College on Education and ORYX Press.

Wenger, E. (1998). Communities of practice: Learning, meaning and identity. UK: Cambridge University Press.

YÖK. (1981). Higher Education Law. Retrieved from http://www.yok.gov.tr/documents/10279/30217/the_law_on_higher_education_mart_2000.pdf

YÖK. (2014). Üniversitelerimiz. Retrieved from http://www.yok.gov.tr/web/guest/universitelerimiz

Zusman, A. (2005). Challenges facing higher education in the twenty-first century. American Higher Education in the Twenty First Century. John Hopkins University Press. Retrieved from http://www.educationanddemocracy.org/Resources/Zusman.pdf 